\title{
The REQUITE Project: Validating Predictive Models and Biomarkers of Radiotherapy Toxicity to Reduce Side-effects and Improve Quality of Life in Cancer Survivors
}

Citation for published version (APA):

West, C., Azria, D., Chang-Claude, J., Davidson, S., Lambin, P., Rosenstein, B., De Ruysscher, D., Talbot, C., Thierens, H., Valdagni, R., Vega, A., \& Yuille, M. (2014). The REQUITE Project: Validating Predictive Models and Biomarkers of Radiotherapy Toxicity to Reduce Side-effects and Improve Quality of Life in Cancer Survivors. Clinical oncology, 26(12), 739-742. https://doi.org/10.1016/j.clon.2014.09.008

Document status and date:

Published: 01/12/2014

DOI:

10.1016/j.clon.2014.09.008

Document Version:

Publisher's PDF, also known as Version of record

Document license:

Taverne

Please check the document version of this publication:

- A submitted manuscript is the version of the article upon submission and before peer-review. There can be important differences between the submitted version and the official published version of record. People interested in the research are advised to contact the author for the final version of the publication, or visit the DOI to the publisher's website.

- The final author version and the galley proof are versions of the publication after peer review.

- The final published version features the final layout of the paper including the volume, issue and page numbers.

Link to publication

\footnotetext{
General rights rights.

- You may freely distribute the URL identifying the publication in the public portal. please follow below link for the End User Agreement:

www.umlib.nl/taverne-license

Take down policy

If you believe that this document breaches copyright please contact us at:

repository@maastrichtuniversity.nl

providing details and we will investigate your claim.
}

Copyright and moral rights for the publications made accessible in the public portal are retained by the authors and/or other copyright owners and it is a condition of accessing publications that users recognise and abide by the legal requirements associated with these

- Users may download and print one copy of any publication from the public portal for the purpose of private study or research.

- You may not further distribute the material or use it for any profit-making activity or commercial gain

If the publication is distributed under the terms of Article 25fa of the Dutch Copyright Act, indicated by the "Taverne" license above, 
Editorial

\title{
The REQUITE Project: Validating Predictive Models and Biomarkers of Radiotherapy Toxicity to Reduce Side-effects and Improve Quality of Life in Cancer Survivors
}

\author{
C. West ${ }^{*}$, D. Azria †, J. Chang-Claude $\ddagger$, S. Davidson $\S$, P. Lambin ฯ, B. Rosenstein $\|$,

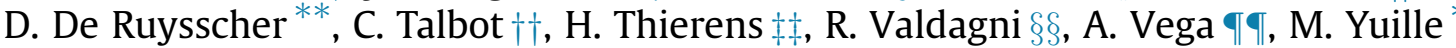 \\ *University of Manchester, Manchester, UK \\ ${ }^{\dagger}$ University of Montpellier, Montpellier, France \\ ${ }^{\ddagger}$ German Cancer Research Centre (DKFZ), Heidelberg, Germany \\ ${ }^{\S}$ The Christie NHS Foundation Trust, Manchester, UK \\ `University of Maastricht (Maastro-GROW), Maastricht, The Netherlands \\ "Mount Sinai School of Medicine, New York, NY, USA \\ ** University Hospitals Leuven/KU Leuven, Belgium \\ ${ }^{\dagger}$ University of Leicester, Leicester, UK \\ $\ddagger$ Universiteit Gent, Gent, Belgium \\ ${ }_{\S}^{\S}$ Fondazione IRCCS Istituto Nazionale dei Tumori, Milan, Italy \\ ๑ศ Fundación Pública Galega Medicina Xenómica, Santiago de Compostela, Spain
}

Received 3 September 2014; accepted 4 September 2014

The worldwide number of cancer survivors within 5 years of diagnosis was estimated to be about 28.7 million in 2008 [1]. Many must cope with the long-term effects of treatment, which can affect health-related quality of life $[2,3]$. These issues need to be addressed in a systematic manner in order to enhance the participation of cancer survivors in society and reduce healthcare costs. Sideeffects and quality of life in long-term survivors after radiotherapy are not well researched and the data are rarely collected in a systematic manner in routine follow-up. Also, studies investigating side-effects can be difficult to compare because of the use of different toxicity reporting systems and a lack of pretreatment data, which is important to ensure that side-effects are related to radiotherapy rather than other underlying health problems [4]. Predictive models of radiotherapy toxicity require cross-centre validation for widespread clinical implementation [5]. Genetics is important, but no biomarker has been validated for clinical use. Predictive model research has the potential to not only improve quality of life, but also to increase survival, for example by using isotoxic strategies [6], and to decrease healthcare costs with a more rational use of expensive medical technology such as proton therapy [7].

\footnotetext{
Author for correspondence: C. West, University of Manchester, Christie Hospital, Wilmslow Road, Manchester M20 4BX, UK.

E-mail address: Catharine.west@manchester.ac.uk (C. West).
}

\section{The REQUITE Project}

REQUITE is funded by the European Union through its Seventh Framework Programme. The objectives of the project are to: (i) carry out a multicentre, cohort study collecting blood samples, epidemiology and treatment data, longitudinal side-effect and quality of life data (before and after treatment, years 1 and 2); (ii) produce a centralised database and biobank of DNA for 5300 patients; (iii) validate published biomarkers of radiosensitivity; (iv) validate clinical predictors of radiotherapy toxicity and incorporate biomarker data; (v) design interventional trials to reduce long-term side-effects; (vi) provide a resource for dissemination and exploitation to the radiotherapy community. The project focuses on cancers of the breast, lung and prostate.

\section{Questionnaires for Collecting Patient- reported Quality of Life and Toxicity Data after Radiotherapy}

Patient-reported outcomes of health-related quality of life and toxicity are different, but can provide complementary information [8]. The European Organization for Research and Treatment of Cancer (EORTC) quality of life questionnaires have been translated and validated into 
81 languages. However, quality of life is a subjective measure that is affected by a person's ability to adapt to adversity, and the questionnaires have diverse domains that are not specific for radiotherapy (e.g. social support, spirituality). The side-effect end points that are most important for radiotherapy are irreversible and show a radiation dose response, such as change in breast appearance [9], pneumonitis [10] and rectal bleeding and faecal incontinence [11].

Questionnaires were developed to enable the collection of patient-reported toxicity data after radiotherapy using the late effects in normal tissues (LENT) scales for patients with gynaecological [12] or prostate [13] cancer. The questionnaires were revised to collect CTCAEv3 data, which incorporated LENT items, for patients with female [14] and male [15] pelvis cancers and produced for head and neck cancer [16]. The questionnaires were validated to check for reliability, compliance and acceptability and were freely available [17]. The female pelvis questionnaire was translated into Afrikaans, Hindi, Marathi and Portuguese for use in an international trial.

\section{Further Development of Patient-reported Toxicity Questionnaires for the REQUITE Study}

A patient-reported toxicity questionnaire is not being used for breast cancer patients because the items are covered in healthcare professional-reported toxicity and in quality of life tools. A lung questionnaire [18] was revised via consultation with REQUITE investigators. The previously developed and validated male pelvis questionnaire was used. Both questionnaires were translated into multiple languages. The following procedures were followed for the lung and male pelvis questionnaires: (i) two native speakers (American, Dutch, French, Flemish, German, Italian, Spanish) translated the English questionnaires independently; (ii) translations were merged into a single forward translation by a third person and any discrepancies resolved via discussion (no disagreements were identified during this process that would have required use of alternative wording for resolution by backward translation); (iii) two native English speakers independently back translated the questionnaires into English and a single back-translated version was sent to an independent reviewer; (iv) differences were itemised and resolved via discussion; (v) questionnaires were tested in 10-15 patients in each country and patients asked to complete a short questionnaire asking whether any questions were confusing or embarrassing (none was identified). These validated questionnaires are available at www.requite.eu.

\section{REQUITE Observational Study, Database and Biobank}

The target recruitment is 5300 patients with breast, lung or prostate cancer. The primary end points are change in breast appearance at 2 years measured using photographs, pneumonitis at 1 year and rectal bleeding at 2 years. The primary end points were selected because they show radiation dose-response relationships. Patients are being recruited in centres in Belgium, France, Germany, Italy, the Netherlands, Spain, UK and USA. The initial phase of the project started in October 2013, with the first patient recruited at the Icahn School of Medicine at Mount Sinai on 10 April 2014. During the first 6 months of the project, work focused on producing standardised case report forms for collecting data, including health professional and patientreported toxicity using the CTCAEv4 system. Quality of life is being assessed using the well-validated EORTC forms. The case report forms are available on the REQUITE website.

Centralised DNA extraction and biobanking is managed at the University of Manchester [19,20]. A second blood sample is stored locally for future RNA analysis. The centralised database with electronic case report forms for healthcare professionals and patient questionnaires is managed by the University of Leicester [21,22]. The database will store breast photographs, full three-dimensional dosimetric distributions in DICOM format and dose-volume histogram files. All data will be anonymised for use by researchers, and patients are asked to consent to future sharing of anonymised data, including across international borders.

\section{Validating Predictive Models}

A number of factors influence the development of radiotherapy toxicity [23]. These factors emerged from: analysis of clinical trials where long-term toxicity data were collected; generally small studies set up to investigate longterm side-effects; or retrospective studies that focused on severe effects that are reported in patients' notes. The radiation dose and the volumes of normal tissue irradiated are obviously important. There is also good evidence that toxicity is affected by: use of additional treatment (surgery, chemotherapy and hormones), comorbidities such as diabetes, older age, smoking and genetic variation.

In recent years, with an increase in data collected, models have been developed to attempt to predict before the start of treatment patients at risk of long-term sideeffects [11]. These emerging models require cross-centre validation to underpin widespread clinical implementation. There is an increasing number of datasets available for validation, but they are variable in terms of the data collected. The REQUITE consortium is accessing existing datasets to validate and/or improve existing clinical models. The prospectively collected standardised data will be used for final validation of the models. The models will be made available via publication in scientific journals and on open source websites (e.g. www.predictcancer.org).

\section{Biomarkers of Radiation Toxicity}

The observational study will also allow for the validation of developing biomarkers. Genetics influences a 
patient's risk of developing side-effects and a number of assays/approaches have been explored to assess a patient's sensitivity to radiation. None has been validated for clinical use. The samples collected in REQUITE will allow for validation of the most promising biomarkers/ approaches. Recently the first replicated genetic associations for adverse reactions to radiotherapy were reported [24]. These should improve predictive models. Centralised DNA extraction and storage will facilitate genotyping later in the project. A flow cytometry method for assessing radiation-induced lymphocyte apoptosis shows promise, with high toxicity after radiotherapy associated with low levels of radiation-induced apoptosis in several independent studies [25]. Three REQUITE centres will carry out the assay with early work focusing on crosscentre standardisation and establishing standardised operating procedures, which will be made available on the REQUITE website. The biorepository will allow for assessment of other promising biomarkers, such as RNA profiles (PAXgene tube collected sample) and mitochondrial DNA [26].

\section{Summary}

REQUITE is using standardised forms and questionnaires, which are available for data collection in other studies. The centralised resource will be accessible to investigate relationships between different toxicity end points and quality of life and ways to identify better dosimetric predictors of toxicity. Deasy et al. [27] highlighted that the way to accelerate progress in improving radiotherapy toxicity predictive models is: 'to begin storing high-quality datasets in repositories' so that 'data could then be pooled, greatly enhancing the capability to construct predictive models that are more widely applicable and better powered to accurately identify key predictive factors'. The REQUITE project addresses the need for data pooling. Of course, the long-term goal of predictive model/assay research is to individualise cancer treatment, which will need decision aids for both radiation oncologists and their patients [28], including information on an individual's likely tumour response and their risk of side-effects. Widespread implementation will require a high level of evidence for benefit (e.g. from randomised trials), including cost-effectiveness and medico-legal issues will need to be addressed (e.g. CE marking, Food and Drug Administration approval). Highquality datasets from multicentre studies of routine cancer patients are essential to underpin progress in predictive model research.

\section{References}

[1] Available from: http://www.iarc.fr/en/media-centre/iarcnews/ 2011/globocan2008-prev.php.

[2] Al-Ghazal SK, Fallowfield L, Blamey RW. Does cosmetic outcome from treatment of primary breast cancer influence psychosocial morbidity? Eur J Surg Oncol 1999;25:571-573.
[3] Barker CL, Routledge JA, Farnell DJ, Swindell R, Davidson SE. The impact of radiotherapy late effects on quality of life in gynaecological cancer patients. $\mathrm{Br} J$ Cancer 2009;100:1558-1565.

[4] De Ruysscher D, Dehing C, Yu S, et al. Dyspnea evolution after high-dose radiotherapy in patients with non-small cell lung cancer. Radiother Oncol 2009;91:353-359.

[5] Lambin P, van Stiphout RG, Starmans MH, et al. Predicting outcomes in radiation oncology -multifactorial decision support systems. Nat Rev Clin Oncol 2013;10:27-40.

[6] Reymen B, van Baardwijk A, Wanders R, et al. Long-term survival of stage T4NO-1 and single station IIIA-N2 NSCLC patients treated with definitive chemo-radiotherapy using individualised isotoxic accelerated radiotherapy (INDAR). Radiother Oncol 2014;110:482-487.

[7] Langendijk JA, Lambin P, De Ruysscher D, Widder J, Bos M, Verheij M. Selection of patients for radiotherapy with protons aiming at reduction of side effects: the model-based approach. Radiother Oncol 2013;107:267-273.

[8] Trotti A, Bentzen SM. The need for adverse effects reporting standards in oncology clinical trials. J Clin Oncol 2004;22:19-22.

[9] Yarnold J, Ashton A, Bliss J, et al. Fractionation sensitivity and dose response of late adverse effects in the breast after radiotherapy for early breast cancer: long-term results of a randomised trial. Radiother Oncol 2005;75:9-17.

[10] Marks LB, Yorke ED, Jackson A, et al. Use of normal tissue complication probability models in the clinic. Int $J$ Radiat Oncol Biol Phys 2010;76:S10-S19.

[11] Fellin G, Fiorino C, Rancati T, et al. Clinical and dosimetric predictors of late rectal toxicity after conformal radiation for localized prostate cancer: results of a large multicenter observational study. Radiother Oncol 2009;93:197-202.

[12] Routledge JA, Burns MP, Swindell R, Khoo VS, West CM, Davidson SE. Evaluation of the LENT-SOMA scales for the prospective assessment of treatment morbidity in cervical carcinoma. Int $J$ Radiat Oncol Biol Phys 2003;56:502-510.

[13] Livsey JE, Routledge J, Burns M, et al. Scoring of treatmentrelated late effects in prostate cancer. Radiother Oncol 2002;65:109-121.

[14] Barraclough LH, Routledge JA, Farnell DJ, et al. Prospective analysis of patient-reported late toxicity following pelvic radiotherapy for gynaecological cancer. Radiother Oncol 2012;103:327-332.

[15] Farnell DJ, Mandall P, Anandadas C, et al. Development of a patient-reported questionnaire for collecting toxicity data following prostate brachytherapy. Radiother Oncol 2010;97:136-142.

[16] Ho KF, Farnell DJ, Routledge JA, et al. Developing a CTCAEs patient questionnaire for late toxicity after head and neck radiotherapy. Eur J Cancer 2009;45:1992-1998.

[17] CTCAE/LENT SOMA questionnaires. http://www.christie.nhs. uk/the-foundation-trust/treatments-and-clinical-services/ clinical-oncology-scoring-treatment-effects/ctcaelent-somaquestionnaires.aspx.

[18] Christodoulou M, McCloskey P, Stones N, et al. Investigation of a patient reported outcome tool to assess radiotherapyrelated toxicity prospectively in patients with lung cancer. Radiother Oncol Aug 52014 [Epub ahead of print].

[19] Harris JR, Burton P, Knoppers BM, et al. Toward a roadmap in global biobanking for health. Eur J Hum Genet 2012;20:1105-1111.

[20] Davis E, Hampson K, Bray C, Dixon K, Ollier W, Yuille M. Selection and implementation of the ISO9001 standard to 
support biobanking research infrastructure development. Biopreserv Biobank 2012;10:162-167.

[21] Beck T, Free RC, Thorisson GA, Brookes AJ. Semantically enabling a genome-wide association study database. J Biomed Semantics 2012;3:9.

[22] Webb AJ, Thorisson GA, Brookes AJ. An informatics project and online "Knowledge Centre" supporting modern genotype-to-phenotype research. Hum Mutat 2011;32:543-550.

[23] Barnett GC, Wilkinson JS, Moody AM, et al. The Cambridge Breast Intensity-modulated Radiotherapy Trial: patient- and treatment-related factors that influence late toxicity. Clin Oncol (R Coll Radiol) 2011;23:662-673.

[24] Fachal L, Gomez-Caamano A, Barnett GC, et al. A three-stage genome-wide association study identifies a susceptibility locus for late radiotherapy toxicity at 2q24.1. Nat Genet 2014;46:891-894.
[25] Azria D, Ozsahin M, Kramar A, et al. Single nucleotide polymorphisms, apoptosis, and the development of severe late adverse effects after radiotherapy. Clin Cancer Res 2008; 14:6284-6288.

[26] Alsbeih GA, Al-Harbi NM, El-Sebaie MM, Al-Rajhi NM, AlHadyan KS, Abu-Amero KK. Involvement of mitochondrial DNA sequence variations and respiratory activity in late complications following radiotherapy. Clin Cancer Res 2009;15:7352-7360.

[27] Deasy JO, Bentzen SM, Jackson A, et al. Improving normal tissue complication probability models: the need to adopt a "data-pooling" culture. Int J Radiat Oncol Biol Phys 2010;76:S151-S154.

[28] Stacey D, Legare F, Col NF, et al. Decision aids for people facing health treatment or screening decisions. Cochrane Database Syst Rev 2014;1:CD001431. 